\title{
Peran Partai Politik Islam dalam Mewujudkan Pemerintahan Ideal (Studi Partai Politik Islam di Kabupaten Bone)
}

\author{
Akbar Tanjung \\ Institut Agama Islam Negeri (IAIN) Bone \\ akbarhukum9601@gmail.com
}

\begin{abstract}
Abstrak
Penelitian ini bertujuan untuk menyelidiki peranan partai politik Islam dalam bidang pemerintahan untuk mencapai tujuan nasional yaitu kesejahteraan rakyat, disamping itu juga untuk menyelidiki kendala yang di hadapi partai politik Islam sehingga kesejahteraan rakyat belum mampu di optimalkan, sehingga dapat memberikan upaya yang bisa di tempuh dalam mewujudkan pemerintahan yang baik demi tercapainya tujuan nasional. Untuk memperoleh data, dilakukan dengan observasi dan teknik wawancara dengan para pengurus partai politik Islam dan Anggota DPRD Kab.Bone fraksi PPP dan PKS. Data yang diperoleh kemudian ditelaah dan dianalisis dengan menggunakan metode deduktif dan induktif.hasil penelitian peranan partai politik Islam belum maksimal memainkan perannya secara keseluruhan. Sehingga muncul sebuah kendala partai politik Islam yakni kondisi Internal, mekanisme yang belum berjalan efektif sehingga tidak mampu mempengaruhi kebijakan publik, hanya sebatas menyampaikan bukan yang menentukan arah kebijakan pemerintah karena kekuatan partai politik Islam di legislatif merupakan suara minoritas. Upaya yang ditempuh berusaha melakukan pembenahan di internal partai khusunya di wilayah sumber daya manusia dengan proses rekrutmen politik yang berkualitas serta memahami prinsip “amar' maruf nahi mungkar” sebagai prinsip pada setiap proses pelaksanaan pemerintahan baik di legislatif maupun di eksekutif.
\end{abstract}

Kata Kunci : Peran Partai Politik Islam, dan Pemerintahan Ideal

\section{PENDAHULUAN}

Sejak awal manusia harus hidup bernegara, manusia tidak bisa lepas dari negara, sehingga sifat itu merupakan konsekuensi manusia sebagai zoon politicon, mahkluk yang tidak bisa lepas dari politik. Manusia sebagai zoon politicon tidak bisa menghindar untuk berpolitik dalam arti ikut menjadi anggota suatu negara. ${ }^{194}$ Suatu negara pasti memiliki suatu sistem politik yang berjalan dan berkembang didalamnya.

Politik sering didefinisikan sebagai penggunaan kekuasaan atau kewenangan , suatu pembuatan keputusan secara kolektif, suatu sumber daya yang langkah atau

${ }^{194}$ Ahmad Sukardja, Hukum Tata Negara dan Hukum Administrasi Negara Dalam Persfektif Fiqh Siyasah, (Cet.I; Jakarta : Sinar Grafika, 2012), h. V

Jurnal Al-Dustur; VOLUME 2 NO 1, JUNI 2019 
sebagai arena pertarungan kepentingan. ${ }^{195}$

Karena itu politik adalah seni dan ilmu untuk meraih kekuasaan secara konstitusional maupun non konstitusional. Itulah sebabnya Morgenthau menyatakan memang ada kecenderungan bahwa meletakkan perjuangan demi kekuasaan adalah jantung politik. Namun apakah betul kekuasaan menjadi poros utama dalam setiap aktifitas politik tanpa memperhatikan perkembangan etis maupun moralitas. Tentu saja ini mengingat kenyataan pula bahwa kekuasaan adalah magnet utama bagi para politisi yang telah menjadi kebiasaan kesehariaan. ${ }^{196}$

Islam mengakui manusia sebagai makhluk berfikir yang kreatif. Kreatifitas itu perlu ditujukan untuk pengaturan kehidupan manusia, yang antara lain, melalui penggalian dan penyusunan aturan-aturan hukum. ${ }^{197}$ Al-qur'an mengandung seperangkat tata nilai etika dan hukum bernegara yang dapat di jadikan pedoman dalam penyelenggaraan pemerintahaan Negara. Bentuk dan sistem pemerintahaan negara diserahkan kepada manusia untuk menetapkan dan mengaturnya. Abdurrahaman Taj menegaskan dengan mengatakan: Setiap umat (bangsa) di berbagai penjuru dunia ini (boleh) mempunyai politik dan hukum-hukum spesifik yang sesuai dengan adat, tatanan kehidupan, dan tingkat kemajuc ${ }_{1} 198$

Adapun dalam pemikiran Islam, politik dikenal dengan siyasah, ilmu yang mengurusi urusan ummat. ${ }^{199}$ Pemerintahaan Islam memiliki sistem khalifah sebagai sebuah kesepakatan berdasarkan kerelaan dan kebebasan memilih tanpa ada pemaksaan dan penyimpangan; pembentukan pemerintahaan berdasarkan baiat, khalifah adalah wakil para pemberi amanat, yaitu rakyat. Umat adalah pemberi kekuasaan. Diantara hak pemberi kekuasaan adalah mengawasi wakilnya. Pengawasan yang paling utama adalah nasihat. Agama adalah nasihat dan sesungguhnya hak rakyat

${ }^{195}$ Mohammad Jafar Hafsah, Politik Untuk Kesejahteraan Rakyat, (Cet, I; Jakarta: PT Pustaka Harapan, 2011), h. 1

${ }^{196}$ Ibid,

${ }^{197}$ Ahmad Sukardja, op,cit , h.27

${ }^{198}$ Ibid, h. 28

${ }^{199}$ Ibid, h .1

Jurnal Al-Dustur; VOLUME 2 NO 1, JUNI 2019 
untuk bermusyawarah dengan wakilnya. ${ }^{200}$

Pengawasan terhadap pemerintah ini tidak akan berjalan tanpa peran partaipartai. Sementara pembentukan partai pun diperintahkan oleh Al-Quran (QS. Al.Imran (03) :104) :



Terjemahan: Dan hendaklah ada di antara kamu segolongan umat yang menyeru kepada kebajikan, menyuruh kepada yang ma'ruf dan mencegah dari yang munkar merekalah orang-orang yang beruntung.

Islam menganjurkan untuk mendirikan partai sesuai dengan ayat diatas, bahwa pengawasan terhadap pemerintah tidak akan berjalan jika tidak ada peran partai-partai di dalamnya. Secara konteks keindonesiaan bahwa hukum di Indonesia menganut sebuah prinsip "amar ma'ruf nahi munkar"(menegakkan kebaikan dan mencegah keburukan).

Partai politik merupakan representation of ideas atau mencerminkan suatu preskripsi tentang negara dan masyarakat yang di cita-citakan karena itu hendak diperjuangkan. Ideologi, platfrom partai atau visi dan misi seperti inilah yang menjadi motivasi dan penggerak utama kegiatan partai.

UUD 1945 pasal 29 ayat (1), menyatakan "Negara berdasarkan Ketuhanan Yang Maha Esa" sila ini menggambarkan bahwa agama atau keyakinan merupakan unsur terpenting dalam Negara Kesatuan Republik Indonesia. ${ }^{201}$ Hal ini sebagai posisi yang strategis bagi terelisasinya fungsi partai yang masing-masing memiliki sebuah

${ }^{200}$ Fahmi Asy-Syannawi, Fiqih Politik “Dinamika Politik Islam Sejak Masa Nabi Sampai Kini”, (Cet I; Jakarta : CV Pustaka Setia, 2006), h. 17

${ }^{201}$ J. Mardimin, Mempercakapkan Relasi Agama \& Negara, (Cet.I; Yogyakarta: GPKI Bekerjasama dengan Pustaka Pelajar, 2011), h. 46

Jurnal Al-Dustur; VOLUME 2 NO 1, JUNI 2019 
orientasi, nilai dan cita-cita atau Ideologi baik pusat maupun daerah, khususnya partai politik Islam di Kabupaten Bone dalam mewujudkan pemerintahan yang baik demi kesejahteraan rakyat .

Partai politik mempunyai posisi (status) dan peranan (role) yang sangat penting dalam setiap sistem demokrasi. Partai yang memainkan peran penghubung yang sangat strategis antara proses-proses pemerintahan denga warga Negara. ${ }^{202}$

Sistem demokrasi Indonesia yang berazaskan kedaulatan rakyat dilaksanakan melalui azas permusyawaratan-perwakilan yang sangat erat hubungannya. Azas permusyawaratan menghendaki agar setiap bentuk keputusan yang menyangkut persoalan-persoalan besar dalam pemerintah diambil melalui musyawarah untuk mufakat. Sistem ini lebih konkret dengan adanya partai politik sebagai bentuk as pirasi masyarakat dengan tetap mensyaratkan bahwa yang menyelenggarakan pemerintah adalah rakyat, rakyat diikutsertakan untuk menyusun kebijakan-kebijakan pemerintah. $^{203}$

Indonesia adalah salah satu negara yang menganut sistem multipartai, dalam artian memiliki lebih dari satu partai dengan berbagai macam ideologi salah satunya adalah partai berbasis Islam, seperti Partai Persatuan Pembangunan (PPP) dan Partai Keadilan Sejahtera (PKS) sesuai dengan kualifikasi KPU.

Salah satu bentuk legitimasi yang membuktikan bahwa partai tersebut merupakan partai Islam adalah dengan melihat aturan partai atau Anggaran Dasar Partai. Dalam pasal

Partai politik yang berbasis Islam yang ada di Indonesia kini telah memiliki dewan pengurus wilayah yang ada di provinsi maupun daerah serta cabang di setiap daerah termasuk daerah Bone yang merupakan salah satu kabupaten yang ada di Sulawesi Selatan. Partai politik yang memiliki ideologi Islam yang sering disebut

\footnotetext{
${ }^{202}$ Prof. DR. Jimly Asshiddiqie, S.H., Pengantar Ilmu Hukum Tata Negara, (Ed.I-Cet. 5; Jakarta : Rajawali Pers, 2013), h.401

${ }^{203}$ Ibid, h. 31

Jurnal Al-Dustur; VOLUME 2 NO 1, JUNI 2019
} 
sebagai partai Islam diharapkan mampu melakukan pengawasan terhadap pemerintah pusat maupun pemerintah daerah di Kab. Bone.

Tatanan masyarakat sebagian besar dipengaruhi oleh politik sebagaimana politik sebagai instrument pemerintah dalam menjalankan peran dan fungsi dalam pemerintahannya, Bone sebagai kota beradat yang memiliki kondisi sosial yang tidak terlepas dari budaya, adat istiadat dan merupakan salah satu daerah yang kondisi penduduknya mayoritas memeluk agama Islam, sehingga hal ini, membuka pintu lebarlebar bagi pihak yang berkepentingan yakni parpol dalam arti sempit dan dalam arti luas yakni seluruh masyarakat Bone untuk lebih progresif dalam mengawal jalannya pemerintahan di Kabupaten Bone khusus dalam hal ikut terlibat dalam penyelenggaran pemerintahan di Kabupaten Bone dan melaksanakannya sebagai bentuk partisipasi politik demi terciptanya masyarakat adil makmur yang di ridhoi Allah SWT.

Dalam suatu negara demokrasi, kedudukan dan peranan setiap lembaga harus sama-sama kuat dan bersifat saling megendalikan dalam hubungan checks dan balances. Oleh karena itu sistem kepartaian yang baik sangat menentukan bekerjanya sistem ketatanegaraan berdasarkan prinsip checks and balances dalam arti luas. Sebaliknya, efektif bekerjanya fungsi-fungsi kelembagaan negara itu sesuai prinsip checks dan balances berdasarkan konstitusi juga menentukan kualitas sistem kepartaian dan mekanisme demokrasi yang dikembangkan di suatu Negara. ${ }^{204}$ Partai politiklah yang bertindak sebagai perantara dalam proses pengambilan keputusan bernegara, yang menghubungkan antara warga negara dengan institusi-institusi kenegaraan. Sebagaimana Robert Michels dalam bukunya, Political Parties, A Sociological Study of the Oligarchial Tendencies of Modren Democrazy, bahwa organisasi merupakan satu-satunya sarana ekonomi atau politik untuk membentuk kemauan kolektif. ${ }^{205}$

Berdasarkan uraian diatas, partai politik Islam sebagai salah satu sarana yang

\footnotetext{
${ }^{204}$ Mohammad Jafar Hafsah, Op.cit, h.402

${ }^{205}$ Ibid, h.403 
berperan untuk mewujudkan pemerintahan Ideal, sehingga penulis mengangkat sebuah judul "Peran Partai Politik Islam Dalam Mewujudkan Pemerintahan Ideal" (Studi Partai Politik Islam Di Kabupaten Bone). Berdasarkan latar belakang diatas penulis memuat suatu permasalahan yaitu Bagaimana peranan parpol Islam di Kab. Bone, Kendala apa yang di hadapi parpol Islam dalam mewujudkan kesejahteraan rakyat di Kab. Bone dan Upaya apa yang ditempuh parpol Islam dalam mewujudkan pemerintahan yang Ideal di Kab. Bone .

\section{TINJAUAN PUSTAKA}

Untuk menghindari terjadinya kesalahpahaman dan kekeliruan dalam menafsirkan judul tersebut, maka penulis mengemukakan beberapa pengertian dari judul tersebut sebagai berikut:

Peran adalah kedudukan atau fungsi. Sedangkan kedudukan merupakan suatu wadah, yang isinya adalah hak-hak dan kewajiban-kewajiban yang merupakan peranan atau "role". 206

Parpol adalah sama dengan partai politik ${ }^{207}$, partai politik berawal dari kata partai yang berasal dari kata Yunani yakni "pars" yang artinya "bagian" atau "bagian dari keseluruhan". Sedangkan politik adalah kekuasaan, pemerintahan dan ketatanegaraan. ${ }^{208}$ Partai Politik adalah kelompok yang terorganisasi yang anggotanya mempunyai orientasi, nilai, dan cita-cita yang sama untuk mencapai kekuasaan. ${ }^{209}$

Partai politik Islam adalah partai yang bertumpu pada ideologi Islam sebagai azaz partai dan memiliki orientasi, nilai dan cita-cita dalam menjalankan fungsinya dalam sistem kenegaraan yang berdasar pada etika politik dalam Islam atau sejalan dengan syariat Islam.

${ }^{206}$ Soerjono Soekanto, Faktor-Faktor yang Mempengaruhi Penegakkan Hukum, Ed. 1 (Cet. 4; Jakarta: PT Raja Grafindo Persada,1993) h. 13

${ }^{207}$ J.T.C. Simoranckir, Kamus Hukum, (Cet. II; Jakarta : Aksara Baru, 1980), h. 124

${ }^{208}$ Ibid, h. 133

${ }^{209}$ Dr. Ir. Mohammad Jafar Hafsah, Politik Untuk Kesejahteraan Rakyat, op.cit, h. 24 Jurnal Al-Dustur; VOLUME 2 NO 1, JUNI 2019 
Pemerintahan secara etimologis berasal dari perkataan pemerintah. sedangkan pemerintah berasal dari kata perintah. Kata tersebut selanjutnya mempunyai arti sebagai berikut :

a. Perintah adalah perkataan yang bermaksud menyuruh melakukan sesuatu;

b. Pemerintah adalah kekuasaan memerintah sesuatu Negara (daerah negara) atau badan yang tertinggi yang memerintah negara (seperti kabinet merupakan suatu pemerintah);

c. Pemerintahan adalah perbuatan (cara,hal urusan dan sebagainya memerintah). ${ }^{210}$

Ideal adalah sesusai dengan cita-cita; sempurna; cita-cita ${ }^{211}$ atau sesuatu yang diangan-angankan ; sesuatu dengan apa yang dinginkan dan dicita-citakan ${ }^{212}$

Pemerintahan ideal adalah dalam pengertian bahasa biasa disebut sebagai good governance atau pemerintahan yang baik.

Hubungan kerjasama yang baik merupakan ciri dan bagian dalam perwujudan pemerintahan yang ideal karena dimana sistem sosial, ekonomi, politik, dikendalikan. Pemerintahan yang baik atau diistilahkan kata governance secara harfiah dapat diartikan sebagai suatu 'kegiatan,'pengarahan,'pembinaan' atau dalam bahasa inggrisnya guilding. Governance adalah suatu proses di mana suatu sistem sosial, ekonomi, atau sistem organisasi dikendalikan dan diatur. ${ }^{213}$

Good governance, pemerintahan yang baik adalah "pelaksanaan wewenanang ekonomi, politik, dan administratif untuk mengelola urusan negara di semua tingkat. Kepemerintahan yang baik mencakup semua mekanisme, proses dan lembaga yang merupakan saluran bagi rakyat untuk mengartikulasikan kepentingan-kepentingan mereka, melaksanakan hak-hak hukum mereka, memenuhi kewajiban-kewajiban h. $22-23$

${ }^{210}$ Pamudji, Kepemimpinan Pemerintahan Indonesia, (Cet. I; Jakarta: PT Bina Aksara, 1982)

${ }^{211}$ Tim Penyusun, Kamus Ilmiah Populer, Apollo, h. 205

${ }^{212}$ Daryanto S.S, Kamus Bahasa Indonesia lengkap, (Jakarta: “Apollo”,1987), h. 273

${ }^{213}$ Sunarso, Perbandingan Sistem Pemerintahan, (Yogyakarta: Penerbit Ombak, 2013), h. 172 Jurnal Al-Dustur; VOLUME 2 NO 1, JUNI 2019 
mereka dan menyambung perbedaan-perbedaan mereka". ${ }^{214}$

Kata good governance pemerintahan yang baik adalah masyarakat harus bersama-sama membantu dalam pengelolaan negara. Sedangkan salah satu ciri daripada kata good governance adalah kesalingterikatan, yaitu bahwa keseluruhan ciri pemerintah mempunyai kesalingterikatan yang saling memperkuat dan tidak bisa berdiri sendiri. ${ }^{215}$

Jadi dapat disimpulkan bahwa pemerintahan yang ideal ketika keseluruhan bidang dapat distabilkan termasuk pula keterlibatan masyarakat di dalamnya. Keterlibatan masyarakat menjadi kekuatan dan penggerak dalam penyelenggaraan pemerintah sehingga pemerintah harus menyelami pola-pola kebiasaan masyarakat agar dapat menciptakan hubungan sosial yang baik.

Kab. Bone dahulu di sebut tanah Bone. Berdasarkan lontara' bahwa nama asli Bone adalah pasir. Dalam bahasa Bugis di namakan Bone adalah kessi 1(pasir). Dari sinilah asal usul sehingga dinamakan Bone. Adapun bukit pasir yang dimaksud kawasan Bone sebenarnya adalah lokasi bangunan Mesjid Raya sekarang ini letaknya persis di Kota Watampone Ibu Kota Kabupaten Bone tepatnya di Kelurahan Bukaka. ${ }^{216}$

Peran partai politik Islam dalam mewujudkan pemerintahan ideal (studi partai politik Islam di Kab. Bone)", dapat di simpulkan bahwa peran merupakan fungsi atau kedudukan sedangkan partai politik Islam sebagai wahana politik bagi setiap warga negara yang membentuk suatu kelompok dan memiliki orientasi, nilai, dan cita-cita yang berlandaskan pada nilai-nilai Islam sebagai dasar dan memiliki fungsi yang baik dalam penyelenggaraan pemerintahan khususnya di Kab. Bone.

${ }^{214}$ Riant Nugroho, Komunikasi Pemerintahan, (Cet. I; Jakarta: PT Elex Media Komputindo Kelompok Gramedia, 2004), h.93

${ }^{215}$ Sunarso. op.cit., h. 175

${ }^{216}$ Ungkapan Toriolo, Gambaran Umum Kab. Bone, http:// sejarah Bone. blogspot.com / 2012 /02/ gambaran- umum- Kabupaten -Bone. html (Tanggal Akses, Sabtu 01/03/2015)

Jurnal Al-Dustur; VOLUME 2 NO 1, JUNI 2019 


\section{METODOLOGI PENELITIAN}

\section{Lokasi Penelitian}

Adapun lokasi dalam penelitian ini adalah di Kabupaten Bone, Kec.Tanete Riattang Barat khususnya di sekretariat partai politik Islam dalam hal ini Partai Persatuan Pembangunan (PPP) dan Partai Keadilan Sejahtera (PKS) Kabupaten Bone. Alasan memilih lokasi tersebut karena di Kec. Tanete Riattang Barat merupakan domisili dari sekretariat parpol Islam sehingga memudahkan penelitian untuk memperoleh data dan informasi yang relevan dengan judul.

\section{Pendekatan Penelitian}

Pendekatan yang digunakan dalam penelitian ini adalah pendekatan normatifempiris dengan menggunakan metode kualitatif. Melalui pendekatan normatif penulis ingin menggali nilai-nilai politik Islam sebagai prinsip dalam penyelengaraan partai Islam di Kab. Bone dalam mewujudkan pemerintahan ideal. Penelitian ini dilakukan berdasarkan data primer responden penelitian ini. Desain ini digunakan untuk melakukan penyelidikan dalam bentuk pemahaman atau konsep dasar politik Islam terhadap gejala-gejala partai politik Islam dalam sosial di Kabupaten Bone, selanjutnya mengolah data yang diperoleh dituangkan dalam bentuk gagasan-gagasan yang bersifat kualitatif sehingga mampu menggambarkan secara jelas tentang permasalahan skripsi ini.

\section{Populasi dan Sampel Penelitian}

a. Populasi Penelitian

Untuk memperjelas data da' ${ }_{52}$ itu penelitian ilmiah, maka penentuan populasi merupakan bagian dan mel.o 52 ....... populasi yang dijadikan obyek dalam penelitian ini. Maka terlebih dahulu perlu di pahami yang dimaksud dengan populasi.

Populasi adalah keseluruhan subjek penelitian. ${ }^{217}$ Menurut Sudjana, populasi adalah totalitas semua nilai yang mungkin, baik hasil menghitung maupun pengukuran, kuantitatif maupun kualitatif, daripada karakteristik tertentu

\footnotetext{
${ }^{217}$ Suharsimi Arikunto, ProsedurPenelitian, (Cet. XII; Jakarta: PT Rineka Cipta, 2002), h. 108 Jurnal Al-Dustur; VOLUME 2 NO 1, JUNI 2019
} 
mengenai sekumpulan obyek yang lengkap dan jelas. ${ }^{218}$

Selanjutnya Sutrisno Hadi menyatakan populasi adalah semua individu untuk siapa kenyataan- kenyataan yang diperoleh dari sampel itu hendak digeneralisasikan. ${ }^{219}$

Populasi adalah himpunan semua individu yang dapat (atau yang mungkin akan) memberikan data dan informasi untuk suatu penelitian. ${ }^{220}$

Dalam suatu kegiatan penelitian yang dilaksanakan, faktor utama yang harus diperhatikan adalah populasi yang menyangkut jumlah secara keseluruhan dari pada objek yang akan diteliti. Populasi sebagai pembatasan objek penelitian didefenisikan oleh Prof Sugiyono sebagai:221 Wilayah Generalisasi yang terdiri atas: obyek/subyek yang mempunyai kualitas dan karakteristik tertentu yang ditetapkan oleh peneliti untuk dipelajari dan kemudian ditarik kesimpulannya.

Populasi dalam penelitian ini terdiri dari seluruh anggota Parpol Islam di Kec. Tanete Riattang Barat Kabupaten Bone.

b. Sampel Penelitian

Sampel merupakan hal yang sangat diperlukan dalam suatu penelitian, mengingat sampel merupakan obyek langsung tempat memperoleh data yang diperlukan.

Sampel merupakan kelompok kecil individu atau bagian dari populasi yang dipilih untuk dilibatkan langsung dalam penilitian. ${ }^{222}$ Oleh karena itu, di dalam menentukan sampel harus diperhatikan unsur-unsur kesamaan populasi, mengingat sampel adalah yang dapat mewakili dan mencerminkan populasi dalam penulisan skripsi ini, mengambil sampel dari seluruh pihak terkait dengan penelitian ini. Adapun sampel dalam penelitian ini adalah PPP

\footnotetext{
${ }^{218}$ Hadari Nawawi, Metode Penelitian Bidang Sosial, (Cet. IX; Yogyakarta: Gadjah Mada University Press, 2001), h. 141

${ }^{219}$ Ibid.,

${ }^{220}$ Gusti Ngurah Agung, Statistika Penerapan metode Analisis untuk Tabulasi Sempurna dan tak Sempurna, (Cet.1;Jakarta :PT. RajaGrafindo Persada, 2003), h. 2

${ }^{221}$ Prof. Sugiyono, Metode penelitian Kuantitatif, Kualitatif dan R\&D, (Cet. XVII; Bandung: CV. Alfabeta, 2012), h. 80

${ }^{222}$ Drs. Ibnu Hajar, Dasar-Dasar Metodologi Penelitian Kwantitatif dalam Pendidikan, (Ed. I, Cet. II; Jakarta: PT. Raja Grafindo Persada, 1999), h. 133 
dan PKS Kab. Bone, respondennya berjumlah 8 orang yang terdiri dari : 3 orang Pengurus Harian DPD PPP, 3 orang Pengurus Harian DPD PKS Kabupaten Bone dan masing-masing 1 orang Anggota DPRD fraksi PPP dan PKS.

\section{Instrumen Penelitian}

Dalam upaya memperoleh data yang akurat, penulis menggunakan instrumen penelitian. Instrumen dalam suatu penelitian menjadi salah satu unsur terpenting karena berfungsi sebagai alat bantu dalam mengumpulkan data. Instrumen-instrumen penelitian yang dimaksud, yaitu:

d. Pedoman wawanara atau dengan menyiapkan daftar pertanyaan agar memudahkan peneliti untuk mendaptkan data-data dari infoman yang dianggap mengetahui dan memahami pembahasan skripsi ini.

e. Kamera Hp, untuk mengambil foto tokoh partai, keadaan kas atau obyek yang akan didokumentasikan.

f. Perekam Suara Hp, untuk Merekam pembicaaraan / wawancara yang berlangsung.

Dengan beberapa alat yang digunakan di atas, dirumuskan berdasarkan atas masalah serta analisis variabel yang terkandung di dalamnya. Tentu saja dalam pengumpulan data-data tersebut di atas, sudah pula diidentifikasikan terhadap jenis data yang akan dikumpulkan.

\section{Teknik Pengumpulan Data}

1. Field research yaitu suatu jenis penelitian yang digunakan untuk mendapatkan data di lapangan (data primer), dalam hal ini Parpol Islam di Kec.Tanete Riattang Barat Kab. Bone.

Dalam mengumpulkan data primer tersebeut peneliti memiliki teknik pengumpulan data sebagai berikut :

a) Observasi yaitu salah satu teknik operasional pengumpulan data melalui proses pengamatan data, pencatatan secara cermat dan sistematis terhadap obyek yang diamati secara langsung. ${ }^{223}$ Metode ini dilakukan dengan

\footnotetext{
${ }^{223}$ Muhammad Teguh, Metodologi Penelitian Ekonomi Teori dan Aplikas, (Cet. II; Jakarta: PT. RajaGrafindo Persada, 2001), h. 133-134 Jurnal Al-Dustur; VOLUME 2 NO 1, JUNI 2019
} 
mengadakan pengamatan langsung yang sistematis di Sekretariat Dewan Pimpinan Daerah (DPD) PPP dan Dewan Pimpinan Daerah (DPD) PKS di Kab. Bone.

b) Wawancara yaitu metode pengumpulan data dengan cara bertanya langsung. Dalam wawancara ini terjadi interaksi komunikasi antara pihak peneliti dan responden selaku pihak yang di harapkan memberikan jawaban. Proses komunikasi antara peneliti dan responden tersebut baru dapat berjalan baik jika masing-masing pihak menyadari adanya kepentingan yang sejalan dari proses komunikasi yang dilakukan. ${ }^{224}$

2. Library research yaitu jenis penelitian yang digunakan untuk mendapatkan data sekunder melalui penelahan dari buku atau data yang bersifat tertulis yang berhubungan dengan objek yang diteliti.

\section{Teknik Pengolahan dan Analisis Data}

1. Teknik Pengolahan Data

Metode pengolahan data yang digunakan dalam tulisan ini adalah pengolahan secara kualitatif yaitu mengolah data dengan bertolak dari teori-teori untuk mendapatkan kejelasan pada masalah, baik data yang terdapat di lapangan maupun yang terdapat pada kepustakaan.

2. Teknik Analisis Data

Setelah semua data yang diperlukan terkumpul, maka selanjutnya mengnailisis data secara:

c. Induktif yaitu dengan jalan menganalisis data yang bersifat khusus lalu mengambil suatu simpulan yang bersifat umum.

d. Deduktif yaitu dengan jalan mengenalisis data yang bersifat umum lalu mengambil suatu simpulan yang bersifat khusus serta menganalisis data secara kualitatif untuk mengolah data atau gagasan yang didapatkan dari informan yang

\footnotetext{
${ }^{224}$ Ibid., h. 136-137
}

Jurnal Al-Dustur; VOLUME 2 NO 1, JUNI 2019 
berkaitan dengan pembahasan skripsi ini dan disajikan dalam bentuk ulasanulasan yang bersifat kualitatif.

\section{HASIL PENELITIAN DAN PEMBAHASAN}

\section{Upaya yang di tempuh Partai Politik Islam dalam Mewujudkan Pemerintahan}

\section{yang Ideal}

Tujuan setiap program kerja yang dicanangkan oleh pemerintah baik pusat maupun daerah haruslah berorientasi pada kepentingan umum yang bersifat demokratis atau dalam konsep Islam di sebut sebagai musyawarah. Partai politik merupakan sarana riil dalam menjalankan nilai-nilai demokrasi haruslah berupaya untuk menciptakan sistem yang akan berujung pada kesejahteraan rakyat sehingga dibutuhkan kerja kolektif, segala unsur negara harus berfungsi secara efektif agar mampu menciptakan tata pemerintahan yang baik dengan menjalankan prinsip-prinsip pemerintahan yang baik dan bertanggung jawab.

Menurut A.Taufik Ketua DPD PKS Kab. Bone, harusnya kita terlibat langsung, khususnya ketika duduk di parlemen dan itu mayoritas maka itu akan lebih mudah mengambil peran-peran kebijakan untuk mensinergikan kebijakan bupati atau eksekutif. Namun dalam hal kordinasi dan komunikasi yang tidak relevan dikarenakan masing-masing mempunyai kepentingan, dengan adanya kepentingan-kepentingan politik yang tidak berdasarkan kepentingan rakyat sehingga memudahkan terjadinya gesekan kepentingan.

"Jadi yang harus di upayakan adalah dengan duduk bersama membicarakan tentang apa yang menjadi masalah selama ini setelah itu baru di cari jalan keluarnya dengan melalui kebijakan-kebijakan program yang akan digulirkan oleh eksekutif dan bekerjasama dengan legislatif akan membuka ruang pemahaman bahwa setiap kebijakan di peruntukkan untuk masyarakat, jadi masyarakatlah yang menjadi perhatian utama dari setiap kebijakan maka 
dengan sendirinya pemerintahan ideal itu bisa tercapai", ${ }^{225}$

Sedangkan menurut Ir. Efendi Sekretaris Komisi II DPRD Fraksi PKS Kab. Bone mengatakan bahwa, tentu berangkat dari cara prekrutan baik dipengurus partai betulbetul yang mempunyai SDM yang maju, memahami tata kelola pemerintahan yang ada termasuk juga untuk memperkuat partai politk dilembaga legislatif tidaklah sembarangan untuk merekrut calon legislatif, jadi ada sistem pengkaderan, ketika membutuhkan orang atau tokoh-tokoh masyarakat untuk direkrut jadi anggota DPR atau DPRD hanya disitu dia sibuk, jadi ini harus kontiniu \]JPPatau berkesinambungan bagaimana pendidikan politiknya, bagaimana sosialisasi di masyarakat bagaimana karakter partai politik Islam, bagaimana memperkenalkan visi-misi partai, anggaran dasar dan anggaran rumah tangga partai, tidak ada yang sifatnya instan semuanya harus berkesinambungan mulai dari dasar, kemudian dalam prekrutan itu ada sebuah persiapan apakah itu dalam bentuk pilkada ataukah pilcaleg tidak instan begitu saja.

"Pada intinya semua bertahap, dengan mempersiapkan kader, baik dalam persiapan yang ditempatkan di eksekutif begitupun di legislatif, semua butuh proses, harus ada progres atau pencapaian bukan pada saat dekat waktu pemilu baru sibuk. Seperti apa yang menjadi program PKS dalam menghadapi pemilu 2019 nanti paling lambat 2017 sudah ada bayangan caleg-caleg yang akan dipersiapkan. Seperti itulah yang menjadi harapan kedepannya jika partai politik Islam bisa menjadi pemenang akan tercipta tata kelola pemerintahan yang lebih baik dari hari ini. jadi SDM-lah yang merupakan hal paling subtantif yang harus siap serta cakap untuk dipersiapkan untuk duduk dalam pemerintahan baik eksekutif maupun legisltaif', 226

${ }^{225}$ A. Taufik, Ketua DPD PKS Kab. Bone, di Kantor DPD PKS Kab. Bone, "wawancara", Tanggal 01 Oktober

${ }^{226}$ Ir. Efendi, Sekretaris Komisi II DPRD Fraksi PKS Kab. Bone, di Warkop Sarlim, "wawancara" Tanggal 10 November 2015 
Menurut Muh. Amin Ketua DPD PPP Kab. Bone mengatakan bahwa, upaya yang di tempuh partai politik Islam dalam mewujudkan pemerintahan ideal :

1. Mendorong penyelenggaraan pemerintahan yang "Maslhatir-Roiyyah", yakni pemerintahan yang mampu menjamin perwujudan kesejahteraan rakyat dan pemenuhan kebutuhan dasar rakyat, memberikan rasa aman, dan tentram melindungi dan mengayomi rakyat serta menjaga persatuan Nasional.

2. Mendorong agar penyelenggaraan pemerintahan, penyelenggaraan negara mendasarkan tindakannya pada kepatuhan hukum dan ketaatan berkonstitusi.

3. Mendorong upaya penegak hukum pemberantasan tindak pidana korupsi untuk mewujudkan pemerintahan yang bersih dan bertanggung jawab. ${ }^{227}$

Jadi dapat disimpulkan bahwa partai politik Islam haruslah berupaya terlibat langsung dalam membangun sebuah komunikasi politik efektif kepada setiap elemen masyarakat agar terjalin sebuah kesepahaman bahwa partai politik sebagai pilar demokrasi yang akan membangun sebuah tatanan pemerintahan yang lebih baik, dan tetap mempersiapkan diri dalam mengambil posisi strategis dalam pemerintahan dengan melakukan pembenahan di internal partai khususnya di bidang sumber daya manusia dari kader partai melalui proses rekrutmen kader yang berkualitas serta akan membawa vivi-misi partai Islam dalam pemerintahan dengan prinsip amar ma'ruf nahi mungkar sebagai bentuk pegawasan partai terhadap pemegang kedaulatan dengan tetap patuh dengan hukum serta tertib dalam menjalankan AD-ART setiap partai sehingga partai memiliki karakter yang sifatnya visioner, bermartabat. bermoral dan mengedepankan semangat humanisme.

Politik berkarakter merupakan hal yang penting karena, menyngkut tata cara dalam tindakan politik, politik karakter sangat dibutuhkan untuk memelihara keharmonisan dalam pergaulan politik.

Partai berkarakter sangat selektif dalam melakukan proses rekrutmen politik. Karena

\footnotetext{
${ }^{227}$ Muh. Amin, Ketua DPD PPP Kab.Bone, di Kantor DPD PPP Kab. Bone, "wawancara”, Tanggal 06 Agustus 2015 
rekrutmen politik yang adil, transparan, dan demokratis pada dasarnya adalah memilih orang-orang ynag berkualitas dan mampu memperjuangkan nasib rakyat banyak untuk mensejaterahkan rakyat dan menjamin kenyamanan dan keamanan hidup bagi setiap warga negara.

Oleh karenanya, tidaklah berlebihan jika dikatakan bahwa rekrutmen politik mengandung implikasi pada pembentukan cara berfikir, bertindak dan berprilaku setiap warga negara yang taat, patuh terhadap hak dan kewajiban, namun penuh dengan suasana demokrasi dan keterbukaan bertanggung jawab terhadap persatuan dan kesatuan bangsa dalam wadah Negara Kesatuan Republik Indonesia.

Berdasarkan hasil wawancara yang dilakukan maka peneliti dapat menyimpulkan bahwa peranan partai politik Islam di Kab. Bone belum maksimal, dikarenakan upaya yang dilakukan hanya sebatas seremonial, meskipun pada pemilukada 2013 yang lalu PPP dan PKS merupakan partai pemenang pengusung Bupati Bone. Secara internal tidak banyak yang dilakukan dalam hal menjadi jembatan pemerintah ke masyarakat, konstribusi partai hanya sebatas menjadi partai pemenang pengusung Bupati Bone.

\section{PENUTUP}

1. Secara umum peranan partai politik Islam di Kab. Bone sebagai perpanjangan tangan rakyat kepada pemerintah begitupun sebaliknya, sebagai wadah yang sangat penting dalam sistem demokrasi untuk mencapai tujuan nasional yang membuka ruang untuk setiap warga negara untuk berpartisipasi dalam setiap proses pemerintahan sebagaimana visi-misi dari partai Islam, namun pada kondisi partai politik Islam di Kabupaten Bone belum optimal dalam memainkan fungsi dan perannya sebagai partai dakwah dalam menerapkan nilai-nilai Islam. 
2. Kendala yang di hadapi partai politik Islam dalam mewujudkan kesejahteraan rakyat di Kab. Bone di antaranya:

- Faktor Internal partai Islam di kabupaten bone belum ada komitmen partai dalam melakukan pendidikan politik baik dari anggota partai maupun kepada mayarakat secara berkesinambungan, serta belum mampu mensosialisasikan visi-visi partai Islam secara efektif.

- Faktor eksternal partai politik Islam di Kabupaten Bone belum mampu mendudukkan kader-kader terbaik partai lebih banyak di pemerintahan sehingga artikulasi dari kepentingan rakyat belum mampu jadi perhatian dari setiap kebijakan yang diambil dari setiap aspirasi yang dibawa oleh partai dikarenakan tidak sin 73 egislatif dengan eksekutif. Sehingga hal itu menjadi kendala partai dalam mengartikulasikan segala bentuk aspirasi masyarakat.

3. Upaya yang di tempuh Partai Politik Islam dalam mewujudkan pemerintahan ideal adalah partai politik Islam haruslah terlibat langsung dalam membangun sebuah komunikasi politik efektif kepada setiap elemen masyarakat agar terjalin sebuah kesepahaman bahwa partai politik sebagai pilar demokrasi yang akan membangun sebuah tatanan pemerintahan yang lebih baik, dan tetap mempersiapkan diri dalam mengambil posisi strategis dalam pemerintahan dengan melakukan pembenahan di internal partai khususnya di bidang sumber daya manusia dari kader partai melalui proses rekrutmen kader yang berkualitas serta akan membawa vivi-misi partai Islam 
dalam pemerintahan dengan prinsip amar ma'ruf nahi mungkar sebagai bentuk pegawasan partai terhadap pemegang kedaulatan dengan tetap patuh dengan hukum serta tertib dalam menjalankan AD-ART setiap partai dan sehingga partai memiliki karakter yang sifatnya visioner, bermartabat. bermoral dan mengedepankan semangat humanisme.

\section{REFERENSI}

Agung, Gusti Ngurah, Statistika Penerapan metode Analisis untuk Tabulasi Sempurna dan tak Sempurna, Cet.1;Jakarta :PT. RajaGrafindo Persada, 2003

Arikunto, Suharmisi, Prosedur Penelitian, Cet. XII; Jakarta: PT Rineka Cipta, 2002

Asshiddiqie, Jimly, Pengantar Ilmu Hukum Tata Negara, Ed.I-Cet. 5; Jakarta : Rajawali Pers, 2013

Asy-Syannawi, Fahmi, Fiqih Politik "Dinamika Politik Islam Sejak Masa Nabi Sampai Kini”, Cet I; Jakarta : CV Pustaka Setia, 2006

Daryanto , Kamus Bahasa Indonesia lengkap, Jakarta: “Apollo”, 1987

Departemen Agama Republik Indonesia, Al Qur'an dan Terjemahan, (Terbitan: Duta Ilmu Surabaya)

Djazuli, A, Fiqh Siyasah "Implementasi Kemaslahatan Umat Dalam Rambu-Rambu Syari'ah", Cet. I; Bogor : Fajar Interpratama Ofslet, 2003.

Hafsah, Mohammad Jafar, Politik “Untuk Kesejahteraan Rakyat”, Cet. I; Jakarta : PT Pustaka Sinar Harapan, 2011

Hajar, Ibnu, Dasar-dasar Metodologi Penelitian Kwantitaif dalam Pendidikan, Ed. . Cet. II; Jakarta : PT. Raja Grafindo Persada, 1999

Hakim, Abdul Aziz, Negara Hukum Dan Demokrasi Di Indonesia, Cet. I; Yogyakarta : Pustaka Pelajar, 2011

Hasan, Hamsah, dkk, Buku Panduan Lengkap Agama Islam, Cet II, Jakarta : QultumMedia, 2010 
Http://gerhciks.blogspot.com/ 2012/ 10/ sistem-pemerintahan. html, Gerhciks, Sistem Pemerintahan, (Tanggal Akses, Sabtu 28 Februari 2015)

Http:// id.m.wikipedia.orang, Wiki, Gambaran Umum Kabupaten Bone, (Tanggal Akses, jum'at, 20 Februari 2015)

Http:// m.berdkarionline.com, Rudi Hartono, Kajao Laliddong, Pemikir Politik Dari Tanah Bugis, (Tanggal Akses, Sabtu, 21 Februari 2015

Http:// www.telukbone.org, Ruslan, Latenrilawa, Sejarah Bone, (Tanggal Akses, Kamis , 25 September 2014)

Http:// www.Uin-alauddin.ac.id, Muhammadiah, Islam dan Good Governance: Perspektif Hak Asasi Untuk Pelayanan Publik, (Tanggal Akses, Senin, 02 Maret 2015)

Kadir Kurdi, Abdulrahman Abdul, Tatanan Sosial Islam, (Cet I; Yogyakarta: Pustaka Pelajar Offset, 2000

Khallaf, Abdul Wahhab, Politik Hukum Islam, terj. Zainuddin Adnan, Cet. I; Yogyakarta:Tiara Wacana, 1994

Khatimah ,Husnul, Penerapan Syari'ah Islam, "Bercermin pada Sistem Aplikasi Syari'ah Zaman Nabi", Cet.I; Yogyakarta : Pustaka Pelajar, 2007

Koesnardi, M dan Ibrahim, Harmaily,Pengantar Hukum Tata Negara Indonesia, Cet. VII; Jakarta Selatan : PD Budi Chaniago, 1988

Mardimin, J, Mempercakapkan Relasi Agama \& Negara, Cet. I; Yogyakarta : GPKI Bekerjasama dengan Pustaka Pelajar Yogyakarta, 2011

Mughniy, al-Saifuddin, Ketika Rakyat Harus Memilih, Refleksi Demokratisasi Lokal, Kalam Nusantara

Nawawi, Hadari, Metode Penelitian Bidang Sosial, Cet. IX;Yogyakarta: Gadjah Mada University Press, 2001

Nugroho, Riant, Komunikasi Pemerintahan, Cet. I; Jakarta: PT Elex Media Komputindo Kelompok Gramedia, 2004

Notowidagdo, Rohiman, Ilmu Budaya Dasar Berdasarkan Al- Quran dan Hadits, Ed. I, Cet. II; Jakarta: PT. RajaGrafindo Persada, 1997

Pamudji, Kepemimpinan Pemerintahan Indonesia, Cet. I; Jakarta: PT Bina Aksara, 1982 
Qodir, Zuly, Sosiologi Politik Islam “ Kontestasi Islam Politik dan Demokrasi di Indonesia”, Cet; 1, Yogyakarta : Pustaka Pelajar, 2012

Rozak, Abdul, Demokrasi, Hak Asasi Manusia, dan Masyarakat Madani, Cet. I; Jakarta: Prenada Media, 2004

Said, Mujahid, Mata Kuliah, Hadis-hadis Siyasah, "Keharusan Adanya Pemimpin"

Siagian, Sondang P, Administrasi Pembangunan, Cet. 7; Jakarta : PT Bumi Aksara, 2009

Sirajuddin, Politik Ketatanegaraan Islam, Cet I; Yogyakarta: Pustaka Pelajar Offset, 2007 